Magdalena Kochmańska

Uniwersytet Pedagogiczny

im. Komisji Edukacji Narodowej

w Krakowie

\title{
Zarządzanie innowacjami w małych i średnich przedsiębiorstwach w warunkach globalizacji
}

Współcześnie organizacje działają w warunkach globalizacji, stąd ich działalność powinna być rozpatrywana z szerszego niż dotychczas punktu widzenia. Umiędzynarodowienie działalności gospodarczej niesie poważne konsekwencje dla menedżerów. Jednym z ważnych zagadnień jest rozwój innowacyjności przedsiębiorstwa i związany z tym rozwój przedsiębiorczości firmy. Jak pisze P.F. Drucker, „Przedsiębiorcy wprowadzają innowacje. Innowacja jest specyficznym narzędziem przedsiębiorczości - działaniem, które nadaje zasobom nowe możliwości tworzenia bogactwa" (Drucker 1992, s. 39). Innowacja i przedsiębiorczość są potrzebne w takim samym stopniu społeczeństwu jak gospodarce oraz przedsiębiorstwom. Potrzebne jest nam społeczeństwo przedsiębiorcze, w którym innowacja i przedsiębiorczość są czymś normalnym, stałym i ciągłym. Podobnie jak kierownictwo jest specyficznym integrującym organem wszystkich współczesnych przedsiębiorstw i instytucji w naszym społeczeństwie organizacji, tak innowacja i przedsiębiorczość muszą stać się integralną czynnością utrzymującą przy życiu nasze organizacje, gospodarkę i społeczeństwo. To wymaga od kierowników we wszystkich organizacjach podjęcia takich działań, aby innowacja i przedsiębiorczość były normalną, bieżącą, codzienną działalnością, aby były praktykowane przez nich oraz przez ich organizacje.

Problematyka zarządzania innowacjami nabiera znaczenia w sytuacji rosnącej globalizacji rynków. Globalizacja powoduje zanikanie wielu barier, czego efektem jest możliwość korzystania przez małe i średnie przedsiębiorstwa z zasobów i umiejętności wytwarzanych poza granicami własnego kraju, łatwiejszy dostęp do najlepszych produktów i usług dla klientów oraz redukcja kosztów komunikacji.

Jedną z charakterystycznych cech współczesnej gospodarki jest szybko rozwijający się proces jej umiędzynarodowienia. Dokonuje się on w dwóch wzajemnie powiązanych i uzupełniających się formach: handlu międzynarodowego oraz umiędzynarodowienia przedsiębiorstw, które to jest formą nowoczesną i bardziej dynamiczną (Lichtarski 2007). Osiąganie celów globalnych małego i średniego przedsiębiorstwa odbywa się poprzez zarządzanie międzynarodowe dzięki:

- efektywnemu wykonywaniu i koordynowaniu funkcji przedsiębiorstwa w skali międzynarodowej za pomocą dostarczania, alokacji i wykorzystania niezbędnych - ludzkich, a także materialnych i niematerialnych - zasobów oraz

- utrzymywaniu przedsiębiorstwa w stanie dynamicznej równowagi w obrębie środowiska międzynarodowego, w którym ono działa.

Małe i średnie przedsiębiorstwa stanowią ponad 99\% wszystkich przedsiębiorstw w Polsce. To przeważająca grupa podmiotów gospodarki narodowej, wywierająca wpływ na wszystkie dziedziny życia społecznego. Małe i średnie przedsiębiorstwa zasługują w Polsce na miano 
motoru napędowego gospodarki, głównie ze względu na ich wkład w tworzenie PKB. W naszym kraju wkład sektora małych i średnich przedsiębiorstw w PKB wynosi 47,4\% (Lublińska-Kasprzak 2009).

Innowacyjność pojawia się w strukturach, w których nie istnieją hierarchiczne powiązania, a relacje międzyludzkie bliskie są powiązaniom typowym dla społeczności lokalnych. Pod koniec XX w. pojawił się termin gospodarka oparta na wiedzy w odniesieniu do sektora firm wykorzystujących zaawansowane technologie, w szczególności techniki informacyjne. W ślad za tym powstała koncepcja teoretyczna systemu gospodarki opartej na wiedzy, której zasadniczym składnikiem jest kapitał intelektualny, ludzki i społeczny.

Innowacje, nierozłącznie powiązane z tym kapitałem, uznane zostały za główny czynnik przesądzający o wzroście gospodarczym, rozwoju w skali regionów, konkurencyjności gospodarki oraz małych i średnich przedsiębiorstw.

Liberalizacja gospodarki prowadząca do globalizacji jest procesem nieodwracalnym. Przejawem tego jest stopniowe znoszenie barier w przepływie kapitału, towarów i usług oraz pracowników. Pojęcia globalizacji i zarządzania globalnego łączą się z podejściem geocentrycznym, tzn. takim, w którym rynki światowe, a nie rynek krajowy, są podstawowym polem działalności małych i średnich przedsiębiorstw.

\section{Przedsiębiorczość a innowacyjność}

Współczesne organizacje funkcjonujące w konkurencyjnym środowisku powinny w sposób ciągły tworzyć (lub przejmować z otoczenia) i wdrażać różnego rodzaju innowacje zabezpieczające efektywność ich działania i rozwoju.

Analizując zmagania innowacyjne organizacji, rodzi się pytanie o przesłanki tych zmagań. Wydaje się celowe przypomnieć, iż pojęcie postępu i rozwoju ma nad wyraz krótki, bo zapoczątkowany w XVII w., rodowód. Przełom w rozumieniu rozwoju wnoszą jednak dopiero prace Darwina, zaś na gruncie filozofii prace Hegla. W czasach nam współczesnych starły się różnorodne koncepcje rozwoju.

W szczególności w związku z pojawiającym się tu i ówdzie zwątpieniem w sens postępu, w możliwość rozwoju, rozwinęły się koncepcje filozoficzne kwestionujące postęp w ogóle. Pytania te pojawiły się w związku z rozwojem fizyki kwantowej, rozpoznaniem procesów nieodwracalnych w fizyce $\mathrm{i}-\mathrm{z}$ drugiej strony - z wystąpieniem zagrożeń ekologicznych współczesnego świata.

Postęp nauki, a w jej wyniku - postęp ekonomiczny i techniczny - nie doprowadził do uszczęśliwienia ludzi. Jednym z czołowych wyrazicieli koncepcji zwątpienia w postęp i rozwój był J. Habermas. Jednak we współczesnej nauce obecny jest też nurt nawiązujący do optymistycznych idei Oświecenia. Jego twórcy, wychodząc z tych samych przesłanek rozwoju nauki, zwłaszcza fizyki kwantowej, i dostrzegając zagrożenia współczesnego świata, akcentują przede wszystkim olbrzymie możliwości twórcze współczesnego człowieka w jego zmaganiu się z rzeczywistością i współtwórczy udział każdej jednostki ludzkiej w stawaniu się współczesności (Huczek 1996).

Społeczeństwo, mając do dyspozycji potencjał naukowy i materialny, działając pod wpływem różnych czynników i stosując innowacje, powoduje postęp (społeczny, organizacyjny, techniczny itd.), który decyduje o tempie rozwoju społeczno-gospodarczego oraz o poziomie warunków życia i pracy.

W interpretacji innowacji dominują dwa podejścia, a mianowicie ujęcia innowacji jako rezultatu lub procesu. W ujęciu pierwszym innowacje to zmiany w sferze produkcji, prowadzące 
w konsekwencji do powstania nowych produktów. W ujęciu drugim innowacje to wielkie procesy twórczego myślenia zmierzające do zastosowania i użytkowania ulepszonych rozwiązań w technice, technologii, organizacji, życiu społecznym, politycznym itp.

Literatura naukowa podaje, że ,pod pojęciem innowacji należy rozumieć przeprowadzone zmiany w technologii, organizacji, ekonomice oraz w sferze społecznej organizacji” (Huczek 1995, s. 19). Nie ma znaczenia, że np. produkty czy technologie znane są gdzie indziej; dla samego społeczeństwa, które ich przedtem nie znało, są one bez wątpienia innowacjami. Dla analizy procesów rozwojowych właściwsze jest takie rozumienie pojęcia innowacji, w którym jest ona nie tylko nowością dla danego społeczeństwa. Argumentację tę można odnieść do niższego szczebla, to jest do gałęzi przemysłu czy też przedsiębiorstwa. Przy analizowaniu zjawisk innowacyjnych w dowolnej organizacji przyjmuje się, że innowacje powinny być nowością w skali tejże organizacji.

Jak podkreśla M. Dolińska, ,Innowacje są nowościami wprowadzonymi w przedsiębiorstwie lub na rynku, jakościowo różnymi od istniejących nowych produktów, rozwiązań technicznych, technologicznych, w sferze zarządzania (personelem, finansami, marketingiem, jakością), w tym w zakresie realizacji procesów produkcyjnych lub organizacyjnych, również powiązanych z otoczeniem rynkowym. Mogą mieć charakter materialny lub niematerialny, a ich efektem są zmiany techniczne, technologiczne, organizacyjne, ekonomiczne, społeczne” (Dolińska 2004, s. 18).

Odnosząc się do pojęcia innowacji, A. Pomykalski pisze, że „obecnie pod pojęciem innowacji rozumie się kompleks zjawisk i procesów obejmujących zarówno powstanie i wdrażanie innowacji, jak i jej efektywność ekonomiczno-społeczną" (Pomykalski 2001, s. 18). Z kolei P.F. Drucker stwierdza: „Innowacja jest raczej pojęciem ekonomicznym lub społecznym niż technicznym” (Drucker 1992, s. 42). Zdaniem W.M. Grudzińskiego i I.K. Hajduka „Wzrostowi innowacyjności gospodarki służyć ma organizowanie infrastruktury instytucjonalnej kreującej innowacyjność, takiej jak parki technologiczne oraz rozwijanie systemu finansowania i gwarancji rynkowych przedsięwzięć innowacyjnych podejmowanych w sferze zaawansowanych technologii (venture capital)" (Grudzewski, Hajduk 2000). A. Francik podkreśla, że terminu innowacja ,używa się do określenia rzeczy nowo wprowadzanej bądź czynności, polegającej na jej wprowadzeniu. Termin innowacja oznacza też koncepcję nowego stanu rzeczy (pomysłu, idei, projektu), czyli inwencję" (Francik 2003, s. 17). Przy czym rozróżnia te dwa pojęcia, tj. innowację i inwencję, twierdząc, że termin innowacja dotyczy zmian wdrażanych do polityki, w odróżnieniu od inwencji, pod którym to pojęciem rozumiemy koncepcję innowacyjną, pomysł, wynalazek. Inwencje są faktami naukowymi naturalnymi pod względem ekonomicznym i dopiero w czasie zastosowania praktycznego stają się innowacjami.

Zdaniem A. Ochojskiego, ,proces innowacyjny - w przeciwieństwie do koncepcji schumpeterowskiej - nie ma charakteru liniowego, lecz jest wynikiem intereakcji i uczenia się na drodze prób i błędów oraz kumulowania wiedzy specyficznej i interdyscyplinarnej” (Ochojski 2006, s. 291). Proces ten ma charakter ciągły i nie oznacza identycznego aplikowania innowacji wszędzie, niezależnie od lokalnych uwarunkowań. Zatem w tym ujęciu, inaczej niż u Schumpetera (wskazującego na innowację jako wynik wysiłków pojedynczego przedsiębiorcy), innowacja jest kreowana przez środowisko lokalne.

Przepływ i wzrost wartości wiedzy w procesie innowacji - uczenia się (ryc. 1) - odbywa się w powtarzającym się cyklu: dostarczanie pomysłów na innowacje, opracowanie rozwiązań innowacyjnych, testowanie i wdrażanie innowacji, promowanie i przygotowanie ich do sprzedaży, tworzenie nowych zastosowań na podstawie wdrożonych wcześniej innowacji. 
Ryc. 1. Przepływ informacji i wiedzy w procesie innowacji

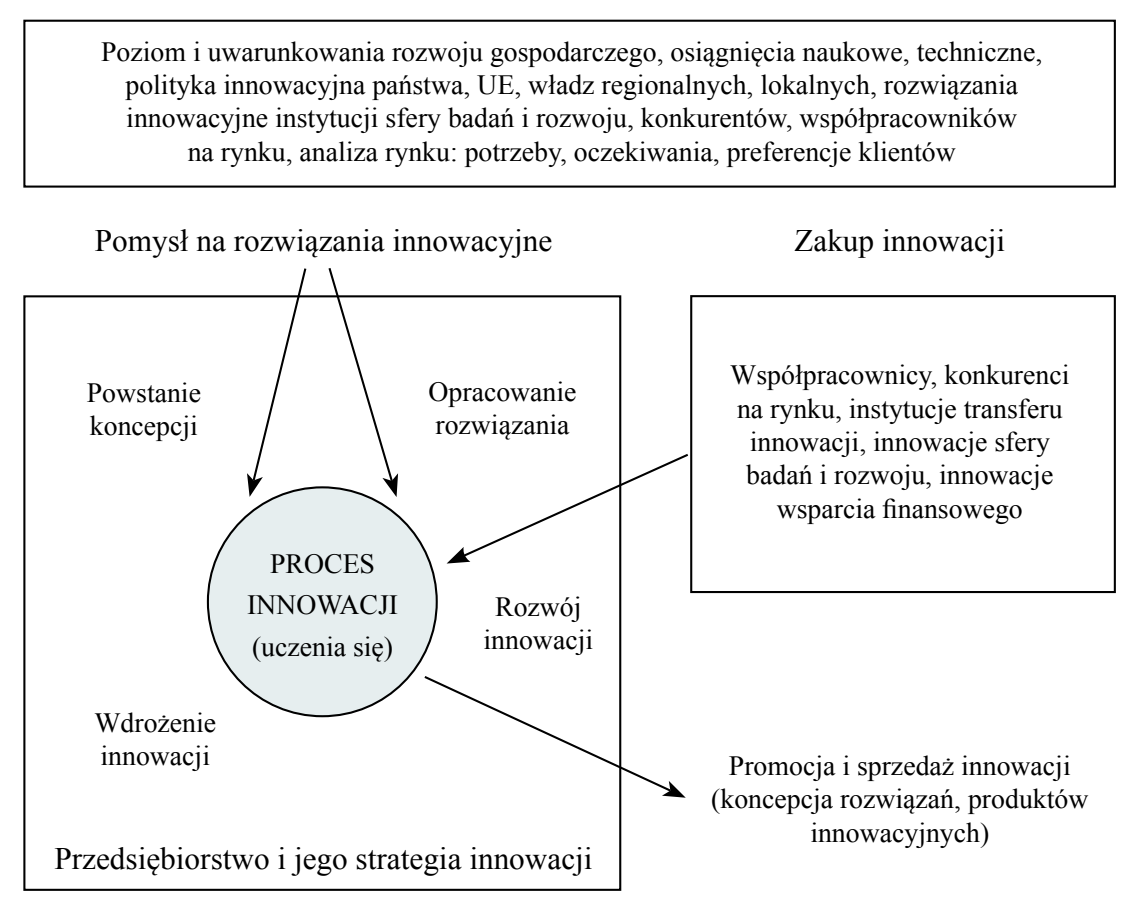

Źródło: M. Dolińska, Innowacje w przedsiębiorstwie, na rynku, w regionie, „Ekonomika i Organizacja Przedsiębiorstw" 2004, nr 9, s. 19.

Efektywność procesu innowacji jest uwarunkowana przepływem i wykorzystaniem w odpowiednim czasie aktualnej informacji i wiedzy oraz zachodzącymi wzdhuż niego relacjami ze współpracownikami na rynku, którzy są zaangażowani w opracowanie, wdrożenie lub transfer i sprzedaż innowacji. Proces ten charakteryzuje się nową organizacją sfery badań i rozwoju, produkcji i marketingu, zgodnie z realizowaną strategią innowacyjną organizacji, ukierunkowaną na osiągnięcie sukcesu rynkowego. Organizacja umacnia wówczas relacje z klientami i współpracownikami, analizuje konkurentów oraz aktualizuje i wykorzystuje bazy danych, które zawierają informacje o rynku i uwarunkowaniach rozwoju gospodarczego, przydatne w tworzeniu wiedzy na temat nowych rozwiązań. P.F. Drucker podkreśla, że „cechą innowacji opartych na wiedzy - i to wyjątkową - jest to, że niemal nigdy nie są wynikiem wpływu jednej dziedziny naukowej, ale kilku różnych dziedzin, przy czym nie wszystkie z nich mają charakter ścisły lub techniczny" (Drucker 1992, s. 124).

Gromadzona i rozwijana w organizacji oraz pozyskiwana z rynku wiedza ułatwia tworzenie i wdrażanie innowacji. Realizacja procesów innowacji w organizacji jest ukierunkowana na wzrost wartości wiedzy zgromadzonej w produktach tej organizacji, w celu większego zaspokojenia potrzeb klientów proponowaną im ofertą o większej wartości. Zgodnie z zasadami marketingu relacyjnego, $\mathrm{w}$ tym stosowanego $\mathrm{z}$ wykorzystaniem systemu CRM, klient uczestniczy aktywnie w tworzeniu i doskonaleniu w czasie oferty organizacji, zgodnej z jego oczekiwaniami i preferencjami. 
Procesy innowacyjne muszą być odpowiednio zarządzane w organizacji, ściśle związane z jej misją i strategią oraz inicjowane zarówno przez rynek, jak i przez wiedzę, a sama organizacja musi być organizacją uczącą się, w której wiedzę i pomysły traktuje się jak zasoby strategiczne.

Organizację można uznać za innowacyjną, jeśli:

- prowadzi w szerokim zakresie prace badawczo-rozwojowe (lub dokonuje zakupów projektów nowych produktów, rozwiązań w zakresie technologii, produkcji, zarządzania),

- systematycznie wdraża innowacje, tj. stosuje nowe rozwiązania w swojej działalności lub w swoich produktach,

- wprowadza innowacje na rynek,

- przeznacza na działalność innowacyjną stosunkowo duże środki finansowe (Dolińska 2004). Istotny jest związek między zmianą a innowacją. Pojęcia te są ze sobą ściśle powiązane. Innowacja zawsze wywołuje zmiany, a nawet jest $\mathrm{w}$ jakimś sensie ich istotą. Zmianie nie musi towarzyszyć konkretna innowacja, chyba że w zakresie pojęcia innowacji znajdą się idee, poglądy i zachowania, czyli sploty relacji ewolucyjnych z pominięciem konkretnych bodźców innowacyjnych.

Każda innowacja prowadzi do zmian w jakiejś sferze funkcjonowania organizacji. W organizacjach zachodzą jednak również zmiany, które nie mają swojej przyczyny w innowacji. Występują też zmiany, które wywołują innowacje; najlepszym tego przykładem są przeobrażenia kultury organizacyjnej prowadzące do kreatywności.

Zmiana dotyczy systemu istniejącego, jest reakcją tego systemu na bodziec w jakimś sensie zewnętrzny, niefunkcjonujący w tym systemie, nieswoisty dla tego systemu, natomiast innowacja jest czymś zewnętrznym, ciałem obcym, które wtargnęło w jakiś sposób do tego systemu. Zmiany pozwalają na wchłonięcie innowacji, czyniąc system organizacji elastycznym. Im większa zdolność organizacji do zmian, tym szybsze wchłanianie innowacji. Jeśli zmiany nie nastąpią, innowacja nie ma szans powodzenia. Pozostaje bowiem ciałem obcym, naruszającym równowagę i odrzucanym poza system. W tym sensie zmiany dotyczą przede wszystkim systemu społecznego. P.F Drucker podkreśla, że ,zmiana jest zawsze tym, co stwarza okazję dla nowego i odmiennego. Systematyczna innowacja polega zatem na celowym i zorganizowanym poszukiwaniu zmian oraz na systematycznej analizie okazji do społecznej lub gospodarczej innowacji, którą taka zmiana mogłaby umożliwiać” (Drucker 1992, s. 44).

Przedstawione wyżej poglądy wskazują, że w pojęciu innowacji zawarte są wspólne cechy, takie jak:

- innowacja jest celową i korzystną zmianą w dotychczasowym stanie zaproponowaną przez człowieka,

- zmiana ta musi znaleźć praktyczne zastosowanie i to zastosowanie po raz pierwszy w danej społeczności,

- przedmiotem tej zmiany są wyroby, technologia, procesy społeczne, ekonomiczne, polityczne, ekologiczne itp.,

- innowacja jest środkiem realizacji celów rozwojowych organizacji oraz pozytywnie wpływa na poprawę efektywności jej pracy.

Innowacyjność społeczeństwa zachodzi w procesie historycznym i wpływ na jej rozwój ma szereg czynników. Literatura naukowa wymienia główne czynniki wpływające na rozwój innowacyjności społeczeństwa, takie jak: osobowość, praca w zespole, związki zawodowe, firmy, klienci, edukacja, rząd, uwarunkowania historyczne oraz czynniki społeczno-gospodarcze (Francik 2003). 
Tworzenie i absorpcja innowacji są znacznie utrudnione długotrwałością struktur społeczno-przemysłowych, w których mogą zachodzić zjawiska i procesy opierające się na mechanizmie autodeterminacji. Struktury te wykazują dużą inercję i odporność na zmiany. A. Francik podkreśla, że „dużą rolę w podnoszeniu innowacyjności przypisuje się dążeniom wolnościowym, pozostającym w opozycji do autodeterminacji i resentymentów. Traktuje się je jako główne motywy zachowań ludzkich. Siłą sprawczą zmian w społeczeństwie nie są jakieś nieokreślone całości społeczne, lecz żywi, konkretni ludzie, którzy charakteryzują się dążeniami wolnościowymi. Wolność wewnętrzną daje im m.in. wiedza, której rezultatem może być innowacja poszerzająca pole wolności, bo stawiająca przed nim nowe cele i sposoby ich realizacji" (Francik 2003, s. 72). Dla rozwoju innowacji bardzo ważne jest miejsce, które zajmuje nasze cywilizacja w kolistych nawrotach historii ${ }^{1}$. Społeczeństwa, które się rozwijają i są kierowane przez światowych przywódców (wszystkich szczebli), przejmują języki i wzorce zachowania tych przywódców. Wtedy to innowacje niosą ze sobą pozytywne zmiany we wszystkich sferach życiowych i czynią to życie lepszym.

A. Francik podkreśla, że „obecnie występuje faza załamania cywilizacyjnego; w pewnym stopniu masy naśladują elity, a ekonomiczny składnik kultury rozbija pozostałe, kierujące cywilizacje na tory nie zawsze sprzyjające człowiekowi. Z możliwości, które stwarza wiedza i technologia, wybieramy tylko niewielką część $i$ to one determinują nasze następne wybory. Problem w tym, że nie wybieramy tego, co piękniejsze i bardziej użyteczne, tylko to, co przynosi szybszy wzrost kapitału i co wydaje się bardziej komercyjne" (Francik 2003, s. 73).

Ważnym czynnikiem rozwoju opartego na innowacjach jest ustrój społeczno-gospodarczy i związane z nim formy własności. W warunkach gospodarki rynkowej istnieją realne możliwości dla formowania innowacyjnego typu rozwoju. Pod pojęciami innowacyjnego typu rozwoju należy rozumieć proces przejścia organizacji i całej gospodarki w całości w nowy jakościowo stan w oparciu o innowacje technologiczne, ekologiczne, organizacyjne i inne, zabezpieczające bardziej efekty i dynamiczny rozwój.

Osobliwością innowacyjnego typu rozwoju w porównaniu z intensywnym typem rozwoju jest to, że działa w nim kompleksowo duża grupa różnorodnych czynników dających synergiczny efekt. Warunkami przejścia do innowacyjnego typu rozwoju są:

- „istnienie wysoko rozwiniętego potencjału naukowo-technicznego,

- wysoka innowacyjna aktywność organizacji,

- działanie efektywnego mechanizmu ekonomicznego w gospodarce,

- rozwój przedsiębiorczości w sferze innowacyjnej,

- istnienie kadr naukowych i menażerskich oraz wysoko kwalifikowanych pracowników zdolnych zabezpieczyć działalność innowacyjną" (Huczek 1996, s. 14).

Sposoby zarządzania zasobami ludzkimi, interakcje z innymi członkami organizacji, kultura organizacyjna itp., w powiązaniu z wartościami i subiektywnie odczuwanymi korzyściami, orientują zachowania ludzi na określone cele i decydują o ich aktywności.

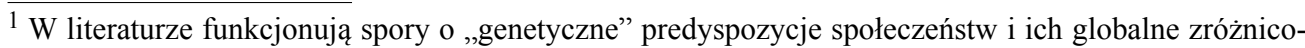
wanie. Teoria kolistej powtarzalności zdarzeń w dziejach ludzkości dzieli cywilizację na wzrastające i dezintegrujące się. Kiedy cywilizacja rozwija się harmonijnie, jej składniki kulturowe (ekonomiczny, polityczny i kulturalny) wzrastają. W cywilizacji dezintegrującej się składniki te konkurują ze sobą, w wyniku czego zaczyna dominować jeden z nich. Wiedza przestaje imponować, pracę twórczą uznaje się za bezwartościową, a etykę i honor za niepotrzebne.
} 
Najistotniejszym z czynników decydujących o stopniu innowacyjności organizacji są ludzie wewnątrz tej organizacji, których istnienie z jednej strony motywuje resztę załogi i wyzwala klimat innowacyjności w sensie ogólnym, z drugiej strony umożliwia przeprowadzenie konkretnych projektów innowacyjnych (Fryzel 2004).

Silny wpływ na rozwój innowacyjności organizacji i regionu ma stan kultury organizacyjnej. Literatura przedmiotu jednoznacznie podkreśla znaczenie kultury organizacyjnej jako istotnego czynnika kształtującego innowacyjność organizacji i społeczeństwa. Sprzężenie zwrotne między innowacją a kulturą charakterystyczną dla danego kraju tworzą w nim niepowtarzalny system zarządzania (Kim, Cameron, Quinn 2003, Stachowicz, Machulski 2001).

P. Drucker pisze, że „uznanie wartości innowacyjności za jeden z najważniejszych celów, do których ludzie powinni dążyć współcześnie, jeśli chcą osiągnąć postęp cywilizacyjny i dobrobyt związane jest z wzorami kultury społeczeństwa" (Drucker 1992). Podstawowym wzorem kultury prorozwojowej jest wytworzenie w danym społeczeństwie nastawienia na sukces i osiąganie sukcesu. Drugim wzorem takiej kultury jest nastawienie na przyczynianie się do osiągnięcia dobra wspólnego - postępu cywilizacyjnego (wzór myślenia i działania innowacyjnego). Trzecim podstawowym wzorem kultury prorozwojowej jest traktowanie zmiany jako szansy na postęp (dobro wspólne), a nie jako zagrożenie dla jednostek i grup społecznych. Te ogólne wzory kultury mogą być podstawą działania całego społeczeństwa lub mogą pojawić się tylko w mniejszych środowiskach lokalnych.

Im bardziej upowszechnione są wzory kultury prorozwojowej, tym większe są szanse na wytworzenie się wzorów innowacyjności i ich upowszechnienie. Im mniej upowszechnione są wzory kultury prorozwojowej, tym wzory kultury innowacyjności realizowane będą w enklawowych, o sprzyjających warunkach brzegowych, środowiskach lokalnych, a społeczeństwo jako całość będzie społeczeństwem zacofanym, pozostającym na peryferiach głównego nurtu przemian cywilizacyjnych współczesności. Postęp cywilizacyjny ograniczony będzie tylko do niewielkich enklaw grup społecznych i instytucji.

W literaturze naukowej funkcjonuje różnorodność klasyfikacji innowacji. Klasyfikacja ta uzależniona jest od szeregu kryteriów, a jedna innowacja może być zakwalifikowana do kilku rodzajów. Jako kryteria podziału innowacji przyjmuje się: złożoność procesu, oryginalność zmian, dziedziny gospodarki (z której się wywodzą), zakres spowodowanych przez nie skutków, stopień nowoczesności, zasięg oddziaływania, warunki psychospołeczne osób je realizujących, korzyści przynoszone społeczeństwu, możliwe skutki zastosowania innowacji, głębokość powodowanych zmian, przedmiot innowacji itd. (Huczek 1996). Dla dalszych rozważań podejmowanych w artykule istotne będą innowacje ze względu na przedmiot innowacji. Wyodrębnia się tutaj innowacje: technologiczne, organizacyjne, ekonomiczne, społeczne i ekologiczne.

Określenie wzajemnych związków między przedsiębiorczością a innowacyjnością nie wydaje się możliwe bez refleksji teoretycznej, a ta wymaga sięgnięcia do teorii Schumpetera. Dla Schumpetera innowacja miała wszechobecny charakter. Przez wprowadzenie nowego produktu (innowacja produktowa) przez otwarcie nowego rynku sprzedaży lub zaopatrzenia (innowacja rynkowa), nowej metody produkcji (innowacja procesowa) lub wprowadzenie nowej struktury działania (innowacja w sferze zarządzania), przedsiębiorca kształtuje nową funkcję produkcji; co pozwala mu osiągnąć zysk, którego podstawę stanowi zdobyta tylko na pewien czas pozycja monopolistyczna. Dla Schumpetera innowacja jest tożsama z przedsiębiorczością (Kwiatkowski 2001). 
S. Kwiatkowski dopuszcza możliwość poważnych modyfikacji już istniejącej funkcji produkcji przez nagromadzenie setek i tysięcy lekceważonych przez Schumpetera subinnowacji. P.F. Drucker przedstawia istotę przedsiębiorczości w ścisłym związku działań przedsiębiorczych i innowacji, za pomocą których zmierza się do sukcesu na rynku. Człowiek przedsiębiorczy zawsze poszukuje zmiany, reaguje na nią i wykorzystuje jako okazję (Drucker 1992). Według P.F. Druckera, „innowacja jest specyficznym narzędziem przedsiębiorczości - działaniem, które nadaje zasobom nowe możliwości tworzenia bogactwa" (Drucker 1992, s. 39).

M. Bratnicki i J. Strużyna piszą, że „możliwe jest dokonanie rozróżnienia pomiędzy innowacyjnością a przedsiębiorczością. Przedsiębiorczość ma cechy procesu, jest sposobem myślenia i robienia rzeczy, w wyniku którego dokonywana jest transformacja innowacji na możliwości rynkowe lub tworzenia przewagi konkurencyjnej” (Bartnicki, Strużyna 2001, s. 40). Organizacje nie są więc w stanie podejmować z zyskiem działań kreatywnych czy też innowacyjnych, jeśli nie mają one charakteru działań przedsiębiorczych. Chociaż trudne jest oddzielenie idei innowacji i przedsiębiorczości, to jednak przyjmuje się, że innowacja jest rezultatem przedsiębiorczego zachowania i przedsiębiorczych strategii istniejących w ramach organizacji.

W tabeli 1 zestawiono przykłady różnych ujęć istoty procesu przedsiębiorczości. Przykłady te przedstawiają związek innowacji z przedsiębiorczością.

Tab. 1. Istota procesu przedsiębiorczości - przykłady różnych ujęć

\begin{tabular}{|l|l|}
\hline Przedsiębiorczość jako proces & \multicolumn{1}{|c|}{ Charakterystyka } \\
\hline tworzenia bogactwa & $\begin{array}{l}\text { przedsiębiorczość wiąże się z podejmowaniem ryzyka i osiąganiem } \\
\text { zysku }\end{array}$ \\
\hline tworzenia przedsiębiorstw & $\begin{array}{l}\text { efektem przedsiębiorczości są nowo powstałe przedsięwzięcia } \\
\text { czy firmy, które wcześniej istniały }\end{array}$ \\
\hline wprowadzania innowacji & $\begin{array}{l}\text { uzewnętrznia się poprzez unikalne kombinacje zasobów, które } \\
\text { czynią istniejące metody i produkty przestarzałymi. }\end{array}$ \\
\hline wprowadzania zmian & $\begin{array}{l}\text { proces przedsiębiorczy pociąga za sobą zmiany poprzez ocenianie, } \\
\text { dostosowanie, modyfikowanie zachowań ludzi, sposobów ich } \\
\text { działania, umiejętności, co umożliwia dostrzeżenie i wykorzystanie } \\
\text { pojawiających się okazji w otoczeniu }\end{array}$ \\
\hline tworzenia nowych miejsc pracy & $\begin{array}{l}\text { przedsiębiorczość łączy się z zatrudnieniem, zarządzaniem } \\
\text { i rozwojem czynników produkcji obejmujących w szczególności } \\
\text { siłę roboczą }\end{array}$ \\
\hline tworzenia wartości & $\begin{array}{l}\text { przedsiębiorczość jest procesem tworzenia wartości dla klientów } \\
\text { poprzez „eksploatowanie” dotąd niewykorzystanych okazji }\end{array}$ \\
\hline wzrostu & $\begin{array}{l}\text { istotą przedsiębiorczości jest silna i pozytywna orientacja na wzrost } \\
\text { sprzedaży, dochodów, aktywów i zatrudnienia }\end{array}$ \\
\hline wykorzystania \\
nadarzających się okazji & $\begin{array}{l}\text { przedsiębiorczość to proces wykorzystania - przez jednostki } \\
\text { działające indywidualnie lub wewnątrz organizacji - szans } \\
\text { dostrzeganych w otoczeniu niezależnie od tego, jakie zasoby } \\
\text { aktualnie znajdują się pod ich kontrolą }\end{array}$ \\
\hline
\end{tabular}

Źródło: T. Kraśnicka, Koncepcja rozwoju przedsiębiorczości ekonomicznej i pozaekonomicznej, Katowice 2002, s. 70. 


\section{Globalizacja a zarządzanie innowacjami}

Istotą globalizacji jest wykorzystywanie praw rynku do zwiększania produktywności gospodarki światowej, a nie tylko wybranych regionów czy krajów. Globalizacja wymusza działania zmierzające do zwiększenia wartości przedsiębiorstw. W warunkach rynku globalnego rosną bowiem szanse rozwojowe tych przedsiębiorstw, które potrafią zwiększać swą wartość dla akcjonariuszy np. poprzez innowacje.

W odniesieniu do przedsiębiorstw globalizacja oznacza m.in.:

- zarządzanie firmą w globalnym otoczeniu,

- zdobywanie globalnej przewagi konkurencyjnej i dążenie do zrównania się z najlepszymi firmami globalnymi,

- wysokie zaangażowanie firmy w operacje na rynkach światowych,

- wykorzystywanie transferów zewnętrznych w zakresie zasobów, technologii, wiedzy oraz innowacji,

- stałe wprowadzanie zmian wynikających z procesów dostosowywania przedsiębiorstwa do uwarunkowań rynków globalnych i potrzeb klientów globalnych (Tubielewicz 2004).

Specyficznymi źródłami korzyści, które mogą zostać uruchomione dzięki globalizacji przedsiębiorstwa, są:

- zwiększenie zysków dzięki wykorzystaniu w skali globalnej wyróżniających kompetencji przedsiębiorstwa,

- możliwości osiągnięcia korzyści z optymalnej lokalizacji działalności firmy w skali światowej przez umiejscowienie jej tam, gdzie może być wykonywana najefektywniej,

- efekty doświadczenia polegające na obniżaniu się kosztu jednostkowego produkcji w miarę kumulowania się ilości wytworzonych produktów dzięki uczeniu się i wzrostowi skali produkcji (Lichtarski 2007).

P. Kotler pisze, że: „Współczesny krajobraz ekonomiczny kształtują dwa kluczowe czynniki: rozwój technologiczny i globalizacja" (Kotler 1999, s. 18). Czynniki te są powiązane, a ich stymulujące działanie na proces rozwoju organizacji powinno być rozważane w ujęciu synergicznym, ponieważ rozwój technologii stymuluje proces globalizacji.

Globalizacja procesu innowacji kształtuje się pod wpływem wielu czynników o różnym pochodzeniu, charakterze, sile i zakresie działania. Można jednak występujące czynniki ująć w następujące grupy:

- rozwój innowacji poprzez rozwój sfery badań i wdrożeń oraz rosnące znaczenie transferu technologii,

- rozwój nowoczesnych gałęzi produkcji i usług,

- konkurencja międzynarodowa, wzrastający popyt na innowacje ze strony globalnie konkurujących przedsiębiorstw,

- polityka gospodarcza, a w tym polityka innowacyjna państwa.

Sukces małego i średniego przedsiębiorstwa na rynku, realizacja ich rozwojowych celów, zależy od procesu tworzenia i dyfuzji innowacji. Innowacja jest oparta przede wszystkim na kompleksowej interakcji pomiędzy pracownikami, przedsiębiorstwem a czynnikami otoczenia. A. Sankowska pisze, że „Innowacyjność przedsiębiorstw to ważny element będący nośnikiem ich pozycji konkurencyjnej oraz źródłem ekspansji na rynki międzynarodowe" (Sankowska 2009, s. 95).

Obecnie coraz częściej mówi się o koncepcji szybkiej innowacji (fast innovation). Szybka innowacja odnosi się do kreowania nowych produktów, usług, modeli biznesowych, procesów oraz rynków wystarczająco zróżnicowanych szybkości, z jakimi przedsiębiorstwo utrzymuje 
przez dekady ponadprzeciętny zwrot dla właścicieli (Georgie, Works, Watson-Hemphill 2005). Uwypukla się w ten sposób konieczność tworzenia innowacji z wyprzedzeniem teraźniejszych i przyszłych konkurentów.

P.F. Drucker podkreśla, że „Innowacja jest pracą zorganizowaną, systematyczną i racjonalną" (Drucker 1992, s. 60). Właśnie dlatego należy wprowadzić zarządzanie innowacjami, w którym przypadkowość w sprawach innowacji zastępuje się systematycznym poszukiwaniem i realizacją szans innowacji i przyjmuje się, że powinno się tak zorganizować przedsiębiorstwo, aby jego struktura nie ograniczała, lecz stymulowała rozwój innowacji. Takie zarządzanie sprawia, że organizacja staje się zdolna nie tylko do innowacji produktowych, procesowych, ale i w sferze samego zarządzania.

A. Pomykalski stwierdza, że „Innowacja jest procesem, a nie, wyrwanym z kontekstu zdarzeniem. Poddaje się więc zarządzaniu. Zarządzanie to jednak sprowadza się do oddziaływania bardziej na proces niż na pojedyncze zachowania. Innowacje podobnie jak jakość są rezultatem procesów pozornie tylko dających się kształtować zachowań" (Pomykalski 2001, s. 78-79).

Istnieje potrzeba efektywnego zarządzania procesem innowacyjnym. Podstawową kwestią jest tu dokładne zrozumienie poszczególnych etapów, przez które przechodzi przedsięwzięcie innowacyjne. Określenie odpowiedniego kierunku rozwoju innowacji i właściwe dostosowanie zasobów to tylko część procesu zarządzania. Przedsiębiorstwo powinno także ustalić specyficzne wymagania dla każdej z faz procesu innowacyjnego oraz efektywnie zarządzać i monitorować przejście z jednej fazy do następnej. Literatura przedmiotu dzieli zarządzanie procesem innowacyjnym na pięć faz (Pomykalski 2001).

Należy podkreślić, że zarządzanie globalne charakteryzuje się:

- globalną strategią,

- globalnym wymiarem podstawowych funkcji gospodarczych, w tym finansowych, marketingowych, badawczo-rozwojowych,

- alokacją podstawowych zasobów przez uwzględnianie warunków ich pozyskiwania na rynku światowym,

- infrastrukturą informatyczną dostosowaną do działalności w skali światowej,

- istnieniu globalnych menedżerów.

Jeśli chcemy, aby proces innowacyjny przebiegał sprawnie, musimy właściwie go zorganizować, tzn. odpowiednio skoordynować wszystkie jego fazy. Rozmiar działalności naukowo-badawczej, jej charakter, a także koszty wymagają określonego ukierunkowania na zadania szczególnie ważne i potrzebne. Wynika stąd konieczność określenia potrzeb rynku w zakresie innowacji.

$\mathrm{Z}$ analizy poszczególnych elementów procesu innowacyjnego oraz z analizy powiązań między nimi wynikają warunki, które decydują o efektywności zarządzania procesem innowacyjnym. Są to:

- proinnowacyjny model gospodarki, uwzględniający innowacje jako ważny element rozwoju,

- wspomaganie regulacjami przez państwo, region, małe i średnie przedsiębiorstwa popytu na innowacje,

- poprawa kluczowych powiązań, ścisłe powiązanie (skoordynowanie) różnych faz procesu rozwojowego w systemie innowacji,

- zapewnienie zasobów marketingowych, produkcyjnych, ludzkich, finansowych niezbędnych do realizacji i wdrażania innowacji,

- selekcja i hierarchizacja celów w sferze badań i rozwoju, monitorowanie, ocena efektywności, porównania narodowych i regionalnych programów rozwoju innowacyjności oraz koncentracji zasobów na ich realizacje. 
W zarządzaniu innowacjami szczególnie istotne są relacje otoczenia makro- i mikro- z zasobami małych i średnich przedsiębiorstw oraz z zasobami firmy, które przyczyniają się do rozwoju innowacji. Siły napędzające rozwój gospodarczy są nierozłącznie związane z metodami i stylami zarządzania dynamicznymi organizacjami działającymi w otoczeniu kształtowanym przez procesy globalizacji, internacjonalizacji i koncentracji. Uwarunkowane jest ono na tworzenie wartości, wzrost przedsiębiorczości, w tym intelektualnej, oraz systematyczną innowację. Przejawia szczególną troskę o wzrost wyróżniających zdolności firmy i kluczowych kompetencji oraz przekształcanie ich w przewagę konkurencyjną na rynku krajowym, międzynarodowym i globalnym.

Literatura naukowa podkreśla znaczenie wiedzy organizacji w kreowaniu innowacyjności. A. Sankowska pisze, że „Innowacja związana jest z użyciem nowej wiedzy, nowym użyciem czy kombinacją istniejącej wiedzy. Innowacja może być związana ze zdolnością do kreowania nowej wiedzy dla łączenia wykorzystania wpływu i rozwoju środowiska, otoczenia i sytuacji w samej organizacji" (Sankowska 2009).

Globalne przedsiębiorstwo buduje swoją przewagę konkurencyjną na fundamencie powiązania i wykorzystania zintegrowanej wiedzy centrali oraz filii zagranicznych. Uzyskuje się dzięki temu możliwość akumulacji wiedzy środowiska lokalnego i międzynarodowego raz uruchomienia dźwigni efektywnościowej i osiągania takich korzyści, jak:

- budowa trwałej i efektywnościowej drogi transferu wiedzy lokalnej pomiędzy filiami a centralą przedsiębiorstwa. Prowadzi to do internalizacji tej wiedzy i ożywienia jej tworzenia i przekazywania,

- przyspieszenie opracowywania i wdrażania innowacji produktowych i procesowych dzięki wykorzystaniu wiedzy filii przedsiębiorstwa,

- zmniejszenie kosztów innowacji dzięki transferowi ponadgranicznemu sprawdzonych rozwiązań pomiędzy filiami przedsiębiorstwa,

- zdobywanie wiedzy o kliencie lokalnym oraz możliwości jej wykorzystania do modyfikacji standardowego produktu globalnego.

Zdaniem A. Trzebielewicza, ważnym wyzwaniem dla zarządzania jest wykorzystanie przedsiębiorczości i innowacyjności w procesie ciągłego dostosowywania do zmieniającego się otoczenia lokalnego, regionalnego czy globalnego. Dla małych i średnich przedsiębiorstw działających w tym otoczeniu oznacza to:

- opanowanie technologii informacyjnych i ich wykorzystanie,

- ciągłe tworzenie zdrowego niezadowolenia i dyskomfortu związanego ze status quo przedsiębiorstwa,

- zdolność odkrywania pojawiających się trendów szybciej niż konkurencja,

- umiejętność szybkiego podejmowania decyzji,

- poszukiwania nowych sposobów działania na rynku (Tubielewicz 2004).

Małe i średnie przedsiębiorstwa, które chcą utrzymać przewagę konkurencyjną na rynku, zdobywać nowe produkty i usługi, muszą być bardziej kreatywne i innowacyjne oraz zapewnić swobodny przepływ informacji, umiejętności uczenia się pracowników i myślenia kategoriami celów i wyników ich działalności. Oznacza to przyswajanie umiejętności szybkiego, elastycznego reagowania na sygnały $\mathrm{z}$ rynku oraz związane $\mathrm{z}$ tym stałe przyczynianie się do podnoszenia przez innowacje jakości pracy, produktów i procesów oraz dążenie do racjonalizacji gospodarczej.

Należy podkreślić, że zarządzanie innowacjami jest poszukiwaniem, opartym na posiadanych zasobach, takich rodzajów innowacji, które powodują, że proces innowacji staje się efektywniejszy w konfrontacji z wyzwaniami, które stawiają przed organizacją rynek, konkurencja, klient. 
Innowacje są tym elementem w działalności przedsiębiorstwa, który decyduje o jego charakterze i sukcesach. U podstaw nowoczesnego zarządzania innowacjami powinno znajdować się zrozumienie przez kadrę faktu, że tylko te przedsiębiorstwa mogą przetrwać i nie stracić szansy rozwoju, które będą odpowiednio przystosowywały się do otoczenia. Można określić pewne przesłanki o szczególnej ważności dla rozwoju innowacyjności przedsiębiorstwa:

- innowacja udaje się w pełni tylko wtedy, gdy jej wprowadzenie wspierane jest przez całe przedsiębiorstwo,

- efektywna innowacja oparta jest na strategii, stąd konieczność zintegrowania innowacji z ogólną strategią przedsiębiorstwa,

- powodzenie innowacji zależy od efektywnych powiązań mocnych i słabych stron przedsiębiorstwa z otoczeniem mikro-, makro- i globalnym,

- powodzenie innowacji wymaga ze strony przedsiębiorstwa uruchomiania mechanizmów wprowadzania zmian, a w tym budowania modelu sieciowego - opartego na technologii informacyjnej.

Na rozwój innowacji składa się wysiłek pracowników oraz kapitał potrzebny do opracowania i wprowadzania na rynek nowych produktów, procesów i organizacji. Innowacja staje się więc sprawą przedsiębiorstw i organów władzy publicznej, które obecnie grupują zasoby ludzkie i odpowiednie kapitały. Innowacja jest oparta przede wszystkim na kompleksowej interakcji pomiędzy indywidualnymi jednostkami, przedsiębiorstwami a czynnikami otoczenia. Jednym z ważniejszych czynników wpływających na innowacyjność przedsiębiorstwa, wynikającym ze współpracy z partnerami biznesowymi, jest element zaufania - wiarygodność własna osiągnięta dzięki kompetencjom oraz koncentracja na kluczowych kompetencjach. Jest to ciekawa strategia budowania własnego wizerunku, a tym samym podwyższania własnej innowacyjności poprzez ciekawy mechanizm działania wizerunku na partnerów biznesowych. Ten z kolei wzmacniany jest koncentracją na kluczowych stanowiskach.

Innowacyjne zdolności przedsiębiorstwa wyznaczają m.in.: poziom chłonności na innowacje, skłonność do wysiłków innowacyjnych, stworzenie systemu uczenia się, zdefiniowanie innowacji i rozpropagowanie ich wśród pracowników, właściwy system motywacji innowacyjnej, a także posiadanie elastycznej organizacji otwartej na innowacje oraz poziom zasobów, które można zaangażować w działalność innowacyjną. Istotnym uwarunkowaniem przygotowania i wdrożenia nowych przedsięwzięć jest zdolność wdrożenia innowacji. Jest ona rozumiana jako ogół przesłanek, warunków oraz wymagań niezbędnych do praktycznego urzeczywistnienia konkretnych innowacji.

\section{Literatura}

1. Bratnicki M., Strużyna J., 2001, Przedsiębiorczość i kapitat intelektualny, Wydawnictwo Akademii Ekonomicznej w Katowicach, Katowice.

2. Dolińska M., 2004, Innowacja w przedsiębiorstwie, na rynku, w regionie, „Ekonomia i Organizacja Przedsiębiorstwa", nr 9.

3. Drucker P.F., 1992, Innowacja i przedsiębiorczość. Praktyka i zasady, PWE, Warszawa.

4. Francik A., 2003, Sterowanie procesami innowacyjnymi $w$ organizacji, Akademia Ekonomiczna

w Krakowie, Kraków.

5. Fryzeł B., 2004, Kultura a konkurencyjność przedsiębiorstwa, TNOiK, Toruń. 
6. Grudzewski M., Hajduk I.K., 2000, Wspieranie innowacyjności przedsiębiorstw, „Organizacja i Kierowanie", nr 3, Warszawa.

7. Georgie M.L., Works J., Watson-Hemphill K., 2005, Fast innovation - achieving superior, differentiation speed to market, and increased profitability, „Journal of Economic Perspectives”, nr. 15, New York, Mc Graw-Hill.

8. Huczek M., 1996, Czynniki wzrostu innowacyjności przedsiębiorstwa, BIT, Bielsko-Biała.

9. Kotler P., 1999, Kotler o marketingu. Jak kreować i opanowywać rynki, Profesjonalna Szkoła Biznesu, Kraków.

10. Kraśnicka T., 2002, Koncepcja rozwoju przedsiębiorczości ekonomicznej i pozaekonomicznej, Wydawnictwo Akademii Ekonomicznej w Katowicach, Katowice.

11. Lichtarski J., 2007, Podstawy nauki o przedsiębiorstwie, Wyd. Akademii Ekonomicznej we Wrocławiu, Wrocław.

12. Lublińska-Kasprzak B., 2009, Raport o stanie sektora MSP w Polsce, Polska Agencja Rozwoju Przedsiębiorczości, Warszawa.

13. Ochojski A., 2006, Przedsiębiorczość sektora publicznego a konkurencyjność i rozwój regionu [w:] Przedsiębiorczość i konkurencyjność a rozwój regionalny, A. Klasik (red.), Akademia Ekonomiczna w Katowicach, Katowice.

14. Pomykalski A., 2001, Zarządzanie innowacjami, PWN, Warszawa-Łódź .

15. Snakowska A., 2009, Organizacja wirtualna. Koncepcja i jej wpływ na innowacyjność, Wydawnictwa Akademickie i Profesjonalne, Warszawa.

16. Tubielewicz A., 2004, Zarządzanie strategiczne w biznesie międzynarodowym, WNT, Warszawa.

\section{Management of the Innovation in Small and Medium Companies in Globalization Conditions}

The essence of the process of globalization is using the market mechanism to enhance productivity of the global economy and not only of particular countries or regions. Globalization compels companies to develop and increase their potential. In the worldwide global conditions the more innovation the companies have the more valuable they are for their shareholders. The author of the article presents the strategies of introducing such types of innovation. 